4 - ORIGINALARTICLE

Models, Biological

\title{
Characterization of pseudarthrosis with ultrasound backscattered signals in rats ${ }^{1}$
}

\author{
Caracterização da pseudoartrose com sinais de retroespalhamentos de ultrassom em ratos
}

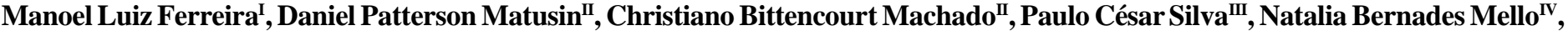
Alessandra Cintra Amaral ${ }^{\mathrm{IV}}$, Renata Schueler Franco ${ }^{\mathrm{IV}}$, Wagner Coelho deAlbuquerque Pereirav ${ }^{\mathrm{V}}$, Alberto Schanaider ${ }^{\mathrm{VI}}$

${ }^{\mathrm{I}}$ Fellow PhD degree, Post Graduation Program in Surgical Sciences, Department of Surgery, Faculty of Medicine, UFRJ, Rio de Janeiro, Brazil.

II Fellow PhD degree, Post-Graduation Program in Biomedical Engineering Program, COPPE, UFRJ, Rio de Janeiro, Brazil.

III Associate Professor, Department of Surgery, Faculty of Medicine, UFRJ, Rio de Janeiro, Brazil.

${ }^{\text {IV }}$ Graduate Student, Faculty of Medicine, UFRJ, Rio de Janeiro, Brazil.

${ }^{v}$ Associate Professor, Biomedical Engineering Program, COPPE, UFRJ, Rio de Janeiro, Brazil.

${ }^{V I}$ Associate Professor and Coordinator of the Post-Graduation Program in Surgical Sciences, Department of Surgery, Faculty of Medicine, UFRJ, Rio de Janeiro, Brazil.
\end{abstract}

\begin{abstract}
Purpose: To propose a novel model of pseudarthrosis in a small animal and to investigate the ability of backscatter parameters from ultrasound signals in differentiating normal bone from those ones with pseudarthorsis. Methods: Twelve Rattus norvegicus albinus free from pathogenic species (SPF) were randomly divided in two groups, with six animals each. In the Control group a surgical approach to the femur was made, followed by the synthesis of the muscle and skin layers. The Experimental group was submitted to an osteotomy of the femur and a vascularized flap of the fascia lata was interposed in the line of the fractured bone. Then the alignment and bone stabilization were accomplished, by using nylon stitch in $U$ shape introduced in holes made in the proximal and distal fractured bone. Bone samples were scanned with ultrasound and signals were collected for each one to analyze the parameter Apparent Integrated Backscatter - AIB. Results: Radiological and anatomopathologic studies revealed the absence of bone consolidation with persistence of fiber-osteoid tissue. Values of the ultrasound parameter AIB from normal bones were statistically different from those with pseudarthrosis. Conclusion: The experimental model was suitable for pseudarthrosis development in rats and the ultrasound backscatter parameters were able to identify such a bone disease in vitro.
\end{abstract}

Key words: Disease Models. Animal. Orthopedics. Ultrasonography. Rats.

\section{RESUMO}

Objetivo: Propor um novo modelo de pseudoartrose em animais de pequeno porte e investigar o potencial de parâmetros de retroespalhamento de ultrassônico em diferenciar osso normal e com pseudoartrose. Métodos: Doze Rattus norvegicus albinus (SPF) foram distribuídos aleatoriamente em dois grupos, tendo cada grupo seis animais. No grupo Controle realizou-se uma abordagem cirúrgica ao fêmur, seguida da síntese por planos do músculo e da pele. O grupo Experimental foi submetido à osteotomia do fêmur aduzida da confecção de um retalho pediculado de fascia lata para interposição entre os segmentos resultantes da fratura induzida cirurgicamente. Prosseguiu-se com o alinhamento e estabilização óssea, mediante a confecção de um nó com fio de náilon em formato de $\mathrm{U}$, introduzido em orifícios efetuados nas extremidades proximal e distal à fratura. As amostras ósseas foram irradiadas pelo ultrassom e sinais foram coletados para cada uma no intuito de analisar o parâmetro Retroespalhamento Integrado Aparente - AIB. Resultados: Estudos radiológicos e anatomopatológicos evidenciaram a ausência de consolidação óssea com persistência de tecido fibro-osteóide. Os valores de AIB para ossos normais foram estatisticamente diferentes em relação aos ossos com pseudoartrose. Conclusão: O modelo experimental apresentou-se adequado para a formação de pseudoartrose em ratos e o parâmetro de retroespalhamento de ultrassom foi capaz de detectar tal doença óssea, in vitro.

Descritores: Modelos Animais de Doenças. Ortopedia. Ultrassonografia. Ratos

${ }^{1}$ Research performed at the Experimental Surgical Center and Post-Graduation Program, Department of Surgery, Faculty of Medicine, Federal University of Rio de Janeiro (UFRJ) and the Laboratory of Ultrasound, Biomedical Engineering Program, COPPE, Brazil.

\section{Introduction}

Bone is a structure found in all species classified as phylum Chordata, subphylum Vertebrata and its main purpose is to provide support for whole body. Bone has an outstanding combination of physical properties, especially the resistance to stretching and compression, some elasticity and porous structure and a relatively light solid mass weight. It is a tissue in constant renewal and 
rebuilding and it stands out for its capacity of self-repair. It can alter its consolidation properties and trabecular geometry in response to mechanical stimulus ${ }^{1}$.

Fracture means a solution of continuity of the bone tissue. An external trauma as a vulnerating agent causes damage of the blood vessels that compose the bone marrow as well as of the adjacent tissues, being this the reason why fractures can trigger local necrotic lesions $\mathrm{s}^{2-4}$. This is one of the deleterious changes that may impair the physiologic healing of the tissue injured ${ }^{2,5}$, but the deformity or absence of bone consolidation may be a consequence of several other etiologies.

Pseudarthrosis is the expression used to describe the nonconsolidation or nonunion of a fracture when the process of bone repairing stops for some reason. The union failure of the fractured bone surfaces establishes the formation of a fibrous or fibrouscartilaginous tissue with the emergence of a serous gap which contains synovial liquid between the fractured extremities ${ }^{6}$. The instability of the fracture site and the lack of appropriate blood supply are two basic mechanisms that contribute to the persistence of this damage.

Quantitative ultrasound (QU) analysis has been extensively explored in the last decades as a means of biological tissue status discrimination ${ }^{7-9}$. Nevertheless, its capacity in the characterization of fibrocartilaginous tissue from pseudarthrosis lesions has not been well explored yet. This characterization method would allow a low-cost and noninvasive assessment of bone.

Considering the high social-economical costs of the sequelae and laboral disability as well as the absence of consensus about early diagnosis and best treatment of the pseudarthrosis, the authors aimed to create an experimental low cost model capable of making possible diagnostic and therapeutic studies for this disease. It is also aimed with this novel model to allow the investigation of the ability of ultrasonographic parameters in differentiating normal and pseudarthrotic bone from in vitro samples.

\section{Methods}

The research was approved by the Ethical Committee for the Use of Laboratory Animals in Research of Faculty of Medicine of the UFRJ.

Twelve young adult rats (Rattus norvegicus albinus), lineage Wistar SPF of both genders, with mean weight of $300 \mathrm{~g}$ at the date of the surgery were randomly distributed as follows: group 1, Control $(n=6)$ and group 2, Experimental $(n=6)$.

The animals obtained from the Center of Experimental Surgery of the Department of Surgery of UFRJ were kept at the same place under controlled temperature, fed with industrialized standard diet and water ad libitum.

The anesthesia was done with Ketamine 5\% (10mg/100g) and Xylazine hydrochloride $2 \%(1 \mathrm{mg} / 100 \mathrm{~g})$, by intraperitonial administration.

After the antisepsis care the surgery took place. In group 1 an incision of 5 - cm long was made over the lateral skin area of the left thigh, with display of the lateral vast muscle and femoral biceps followed by rigorous hemostasis. After identification of the femur it was proceeded the suture of the muscular and skin layers, respectively with 4-0 polyglycolide threads with a cylindrical needle and 4-0 nylon thread with a cutting needle.
In group 2, the surgical access to the femur was the same of group 1. A diaphyseal osteotomy of the femur was done with an electric circular saw in slow rotation, irrigated with physiologic solution $0.9 \%$ to avoid heating of both saw and bone (Figure 1). Close to the fracture ends, perforations were made with hypodermic needles $21 \mathrm{Gx} 1$, with circular movements, through which monofilamentar $U$ shape threads of nylon 3-0 were introduced. A pediculate flap of the fascia lata was inserted between the segments of the fracture with suture of its distal extremity to the semimembranous muscle. Then the proximal and distal segments of the fracture were approximated by tightening the nylon inserted through the needle holes (Figure 2). Finally, it was done the synthesis of the surgical incision at the same way as described for group 1 .

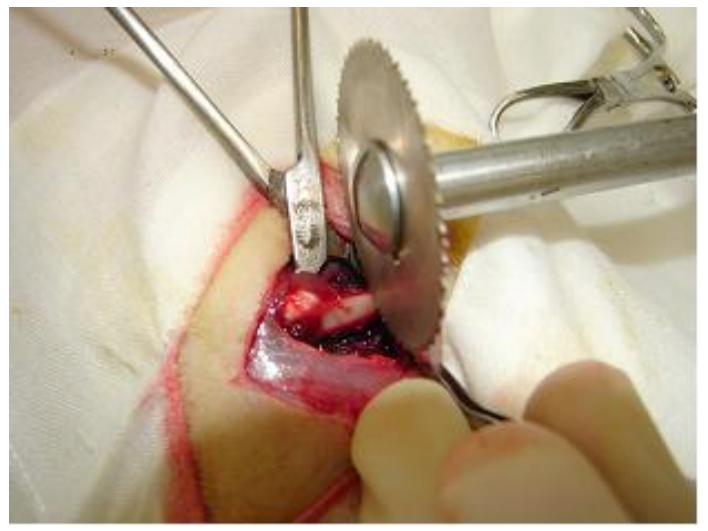

FIGURE 1 - An electric circular saw was used to produce the diaphyseal osteotomy of the femur

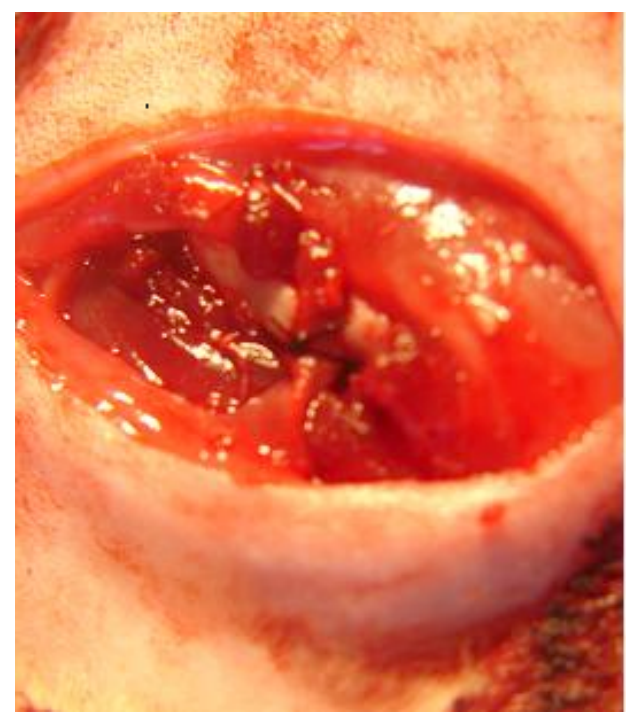

FIGURE 2 - Fascia lata flap (arrow) inserted between the segments of the fracture

The postoperative analgesia consisted of sodium dipyrone (20 drops in $500 \mathrm{ml}$ of water) diluted in the drinking water and changed daily, for 7 days.

After a period of 120 days, radiological studies of the left forward limbs of all animals were performed followed by euthanasia with $4 \mathrm{ml}$ of sodium thiopental $2,5 \%$ by intraperitonial injection in 
order to excise the pseudarthrosis area of the femur for digital radiography with equipment of $100 \mathrm{kV}$ voltage higher, with $1 \mathrm{~mA}$ current and 30 Watts power. Those tissue samples from the femur were fixed in formaldehyde, dehydrated in ethanol, embedded in paraffin and finally stained with Hematoxylin and eosin to microscopic evaluation (at x 250 magnifications).

It was also done an in vitro ultrasonic analysis of four bone samples with pseudarthrosis immersed in physiologic serum at $25^{\circ} \mathrm{C}$, in the focal region of a 5- $\mathrm{MHz}$ circular transducer (Panametrics V326) focalized at $40 \mathrm{~mm}$ (Figure 3). The samples were scanned in a plane parallel to their surfaces and the transducer was displaced in steps of $0.55 \mathrm{~mm}$ (half size of beam diameter in the focal region).

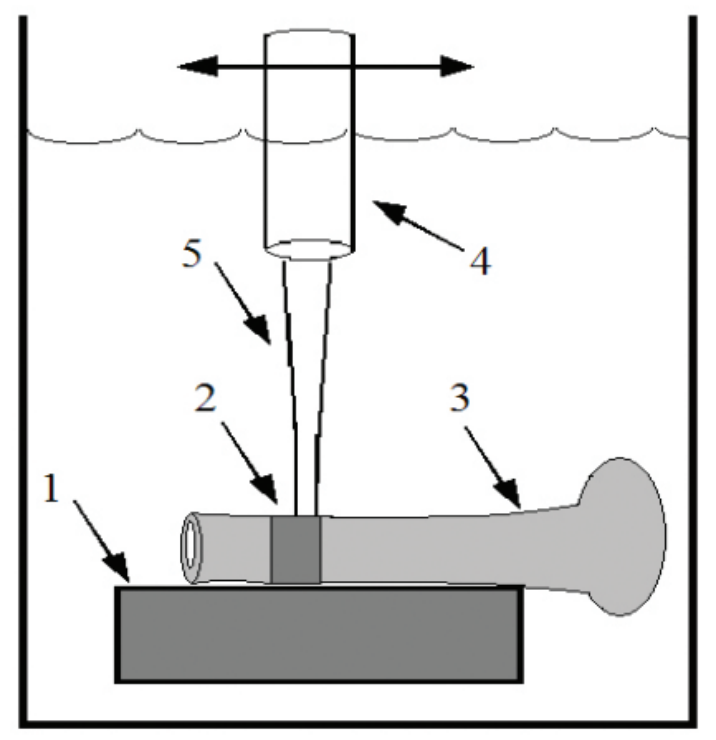

FIGURE 3 - Experimental apparatus: (1) reflector; (2) pseudarthrosis; (3) diaphysis; (4) transducer

An average of five US signals was collected from the pseudarthrosis site and its adjacent bone for each sample. A reference signal was also collected from a steel plate placed at the focal distance. Signals were transferred to a microcomputer where the backscatter parameter (Apparent Integrated Backscatter - AIB $)^{10}$ was obtained (Figure 4).

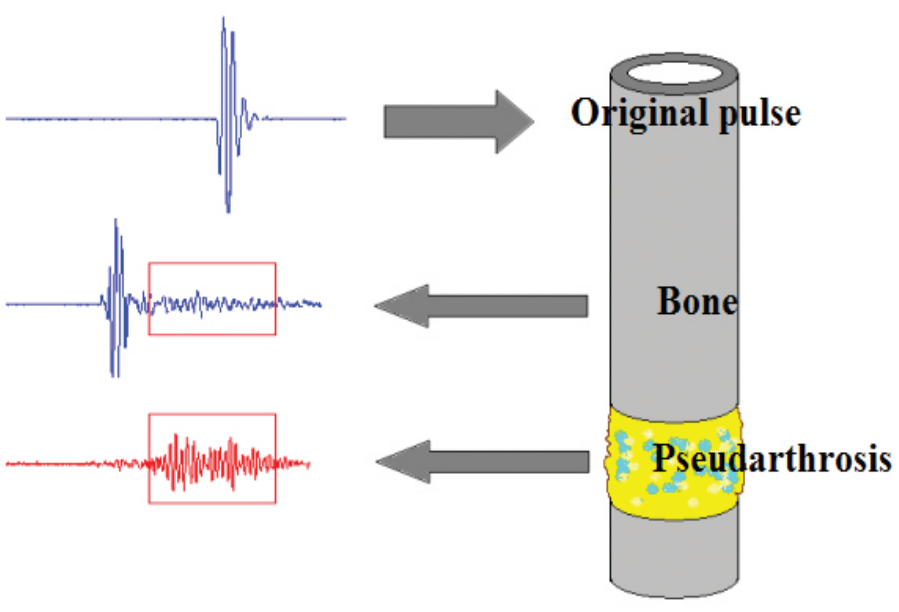

FIGURE 4 - Diagram illustrating the emitted pulse and the received echoes with backscatter signals (red square) of bone and pseudarthrosis
A Kruskal-Wallis test was used to evaluate the null hypothesis that AIB values of pseudarthrosis and bone became from samples with same medians ( $\mathrm{p}$-value $<0.05)$.

\section{Results}

All animals in group 1 recovered without any sequelae. All rats in group 2 showed claudication of the left forward limb and the presence of movement of fracture segments, after a period of 120 days from surgery. The radiography did not reveal bone calcification between the fractured segments (Figure 5). The digital radiography disclosed only small areas of bone calcification with predominance of tissue of nonunion (Figure 6). The histopathological evaluation showed the presence of tissue with fibrous-osteoid aspect (Figure 7).

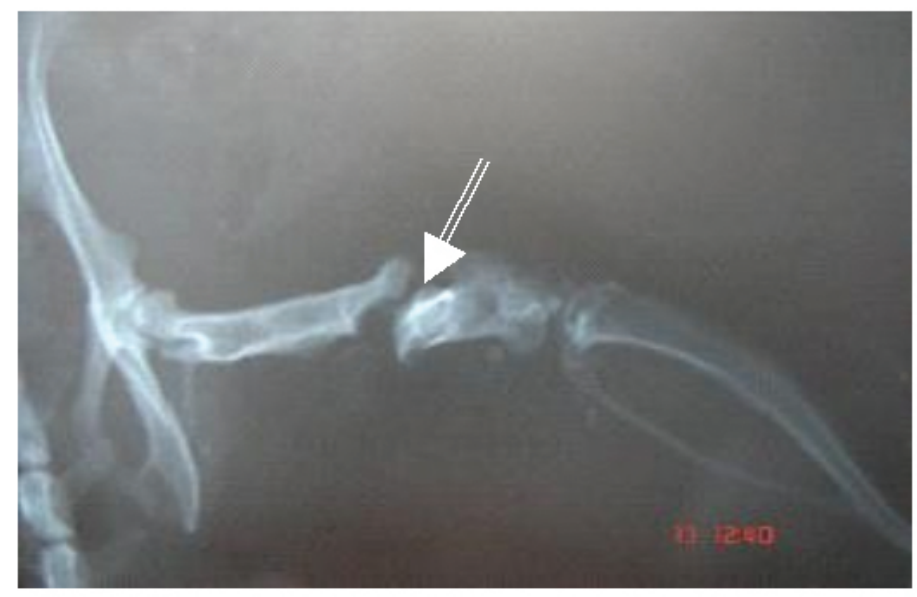

FIGURE 5 - Radiography 120 days after the surgical procedure showing the absence of bone calcification (arrow)

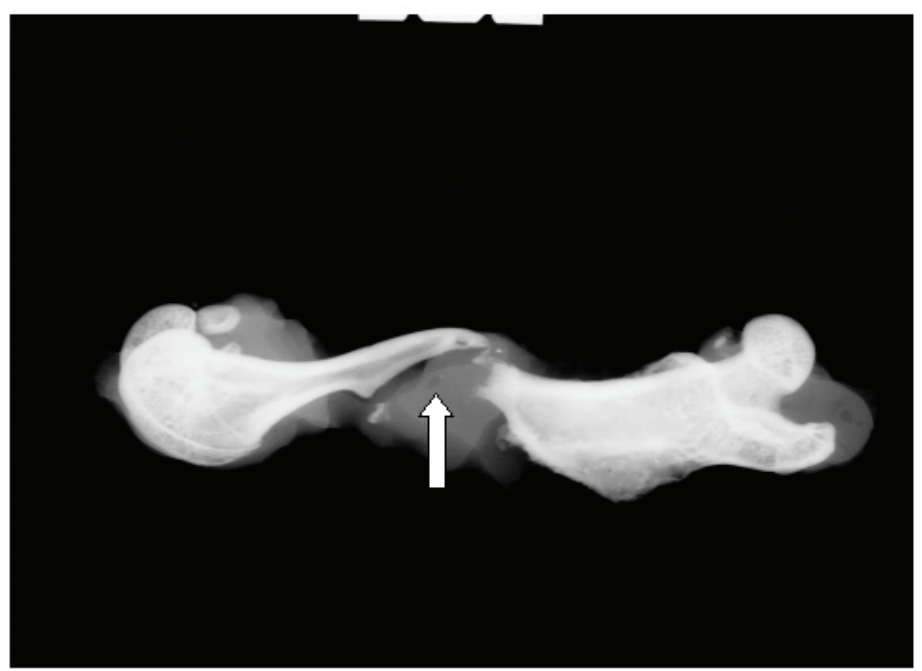

FIGURE 6 - Digital radiography (20kV, 0.41mA and 180s) with presence of tissue of nonunion (arrow) 


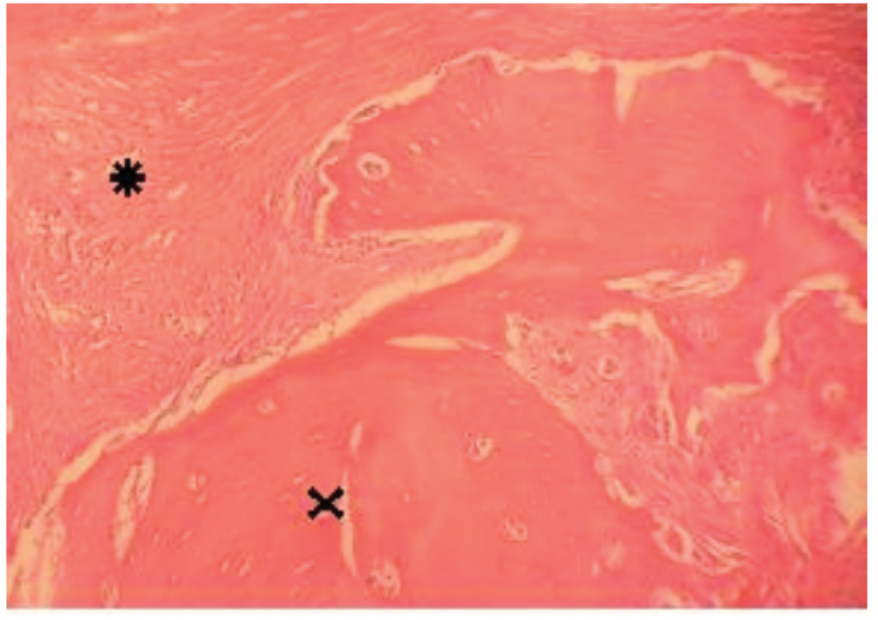

FIGURE 7 - It was observed tissue with fibrous-osteoid aspect (*) among bone tissue ( $\times$ ). HE x 250.

For the ultrasonic parameter AIB, the average values for normal bone and pseudarthrosis was $-43.9 \pm 5.2 \mathrm{~dB}-37.8 \pm 1.1 \mathrm{~dB}$ respectively. There was a significant difference between these two groups ( $\mathrm{p}<0.05$ ). Individual AIB values of tissues for each sample are presented in Figure 8.

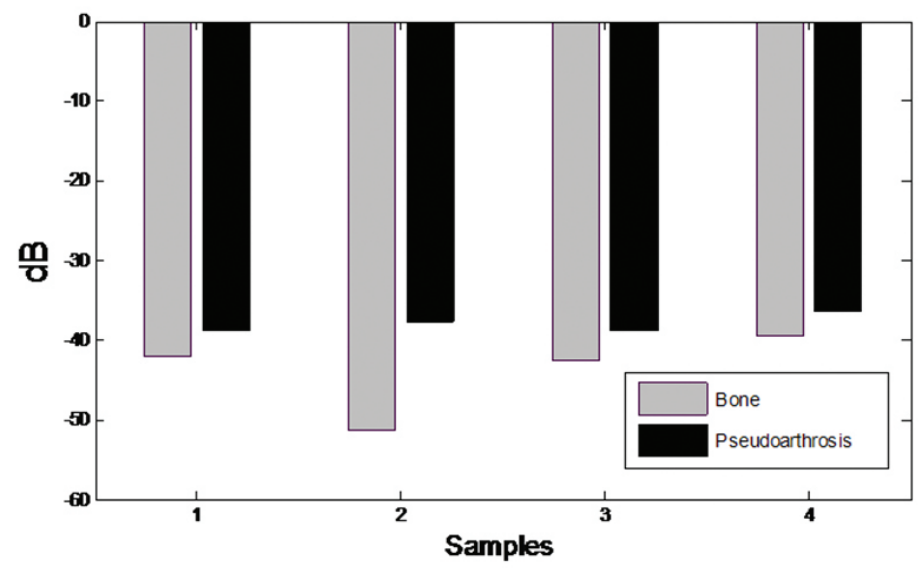

FIGURE 8 - AIB values for pseudarthrosis and the adjacent normal bone of four samples. Significant differences between AIB values for normal bone and pseudarthrosis were found $(p=0.03)$

\section{Discussion}

It is estimated in the United States of America an incidence of 5.6 million of new fractures every year. Nearly 5 to $10 \%$ of those cases have an outcome with pseudarthrosis formation or delay of the bone consolidation ${ }^{11}$.

The causes of non-union or absence of bone consolidation are related to several factors among which stand out: smoking, limbs microangiopathy, metabolic disturbances, hypovitaminosis, prolonged and inadequate immobilization, neoplasic or metastatic disease, hyperparathyroidism, excessive stretch of the fracture with external fixation, open fracture, infection and interposition of soft tissues in the fracture ${ }^{12,13}$.

Many methods have been used in the treatment of pseudarthrosis, such as: osteoperiostal decortication, spongy autograph, BMP (bone morphogenetic protein), stem cell from bone marrow, platelet growth factors, vascularized bone graft, internal stabilization with different materials (compression plate, locked, unreamed intramedullary nail), external stabilizers (external fixators or orthoses), besides ultrasound, shock waves and electromagnetic fields ${ }^{14,15}$. This wide range of options just reflects the absence of a consensus about the best approach for this disease; which may bring about serious conditions like disabilities and deformities with great social and economical burden for the families and the public health services.

The development of appropriate models of pseudarthrosis in animals will improve the knowledge of therapeutic procedures and allow the assessment of a variety of new surgical techniques for obtaining more effective and objective results. Nevertheless, there is a great difficulty to reproduce such models. It is important to emphasize that experimental models wich produce bone fractures are always accompanied by some injury in contiguous tissues ${ }^{16}$.

Several animal species have been used to create a pseudarthrosis ${ }^{14,17-20}$, but the authors usually converge their attention to the relevance of vascularization or to the extension of the bone segment injured.

The choice of rats from Wistar SPF lineage was due to the fact that they are animals of small size, easy maintenance and with anatomical aspects such as bone covered by great muscular mass, comparable to those found in the human species.

The success in obtaining pseudarthrosis in dog's models is variable reaching nearby 86 to $95 \%$ of the experiments described and it takes three to seven months after surgery to be observed ${ }^{19}$. In the current research with rats it was verified $100 \%$ of positive results in the production of this kind of injury within four months after the surgical procedure. Another advantage of the rat model is the lower cost for maintenance with fewer expenses in the operation room. Furthermore this model could be easily used to study the regenerative effect of pluripotencial stem cells. Certainly there will be some trouble to manufacture rigid materials with compatible sizes for therapeutic application in rats. However this could be overcome with some handcraft skill.

Bone healing demands a perfect stability so that the capillaries could promote the revascularization crossing the fracture line and activating the transformation of pluripotential cells in osteoblasts ${ }^{15,21,22}$. That allows primary remodelation without periosteal callus formation. In the rat model used, the formation of cartilaginous tissue was possible because it was found a way of maintaining the movement in the focus of the fracture with guarantee of blood supply integrity. It must be highlighted that if stability is reached naturally or even in the presence of a pseudarthrosis resulting from a fragile fixation of the fracture with monofilament threads, the calcification of the cartilage may occur and callus may be formed in a process of osteochondral repair ${ }^{5,16,22}$. In these cases, most of the times a vicious consolidation results, which means that the extremities can be calcified without alignment and with an axial deviation. So, in the present study, the lack of stability in the fracture line was one but not the single step essential for the development of pseudarthrosis in the rat model. The understanding of this dynamics was crucial to develop the pseudarthrosis model.

Besides the diaphyseal fracture with a less stable fixation, it was of utmost importance to add another step of intervention by the interposition of the pediculate flap of the fascia lata. It must be remembered that not only the $U$ shape suture sustained the maintenance of the fascia lata flap between the segments after the osteotomy but also the fixation maneuver in the semimembranous muscle contributed to avoid its displacement along the postoperative evolution. The surgical procedure described in this work was the key not to let bone calcification happen spontaneously. No similar report was found in the scientific literature on this issue.

The radiological and histopathological data support this model proposal and the persistence of the fibrous-cartilaginous tissue was compatible with a hypertrophic pseudarthrosis pattern.

Pseudarthrosis, which is also related to bone quality, usually has its diagnosis and follow-up done by X-rays, tomography or magnetic resonance images. In the last decade quantitative ultrasound has been applied to bone quality studies, for instance in osteoporosis ${ }^{23}$. Backscattering of sound depends on properties like size and density of scatterers. 
Scattering in bone is attributed mostly to trabeculae, due their high difference of acoustic impedance with marrow bone ${ }^{23-25}$ Although diaphysis bone is poor in trabeculae and has a thick cortex, values of AIB for normal bone showed similar results with trabecular bone tissues for same frequency ${ }^{10}$. AIB is estimated (in decibels) as the ratio of the average power spectrum from scattered signals and the power spectrum from the reference signal. In this way, the energy of scattered signal is a relative measure with respect to the energy coming from a perfect reflector placed at the same distance. Thus the objective was to check if AIB parameter should be capable to differentiate backscatter signals from bone and pseudarthrosis.

Results of AIB values for pseudarthrosis were always higher compared to normal bone including those of the same sample. Perhaps higher values are caused by complex matrix composition made of fibrous tissue, cartilage and calcified points with different acoustic impedance. Moreover, a smaller attenuation and reflection in pseudarthrosis compared to bone permit a great penetration of acoustic energy in water sample interface. Thus, these results are in accordance with a negative correlation between density and backscattering of other authors ${ }^{10}$. However, the number of signals per sample was limited compared to other studies because of the small acquisition sites studied and the convex format of diaphysis bone which made unfeasible a 2-dimention scanning. Comparison with other quantitative methods can be done to correlate density, composition and mechanical properties to ultrasonic parameters $^{8,26,27}$.

Ultrasound backscatter parameters emerge as a nove diagnostic tool in differentiating normal and pseudarthrotic bone. This is a preliminary study and more data is now being collected. At the same way further studies of its sensitivity with in vivo signals need to be done. It is previewed the use of combined parameters ${ }^{28}$ to enhance the detection and characterization of pseudarthrosis and regeneration stages.

\section{Conclusion}

The new experimental model developed in rats has proven to be feasible to the production of pseudarthrosis and will allow its use for testing different therapeutic approaches in such circumstances.

\section{References}

1. Carano RAD, Filvaroff EH. Angiogenesis and bone repair. Drug Discov Today. 2003;8(21):980-9.

2. Muinck ED, Simons M. Re-evaluating therapeutic neovascularization.

J Mol Cell Cardiol. 2004;36(1):25-32.

3. Doblaré M, García JM. On the modelling bone tissue fracture and healing of the bone tissue. Acta Cient Venez. 2003;54(1):58-75.

4. Karladani AH, Granhed H, Kärrholm J, Styf J. The influence of fracture etiology and type on fracture healing: a review of 104 consecutive tibial shaft fractures. Arch Orthop Trauma Surg. 2001;121(6):325-8.

5. Bostrom M, Saleh DJ, Einhorn TA. Osteoinductive growth factors in pre-clinical fracture and long bone defects models. Orthop Clin North Am. 1999;30(4):647-58.

6. Hietaniemi K, Paavolainen P, Penttienen R. Connective tissue parameters in experimental nonunion. J Orthop Trauma. 1996;10(2):1148.
7. Meziri M, Pereira WCA, Abdelwahab A, Degott C, Laugier P. In vitro chronic hepatic disease characterization with a multiparametric ultrasonic approach. Ultrasonics. 2005;43(5):305-13.

8. Hakulinen MA, Töyräs J, Saarakkala S, Hirvonen J, Kröger H, Jurvelin JS. Ability of ultrasound backscattering to predict mechanical properties of bovine trabecular bone. Ultrasound Med Biol. 2007;30(7):919-27. 9. Machado CB, Pereira WCA, Meziri M, Laugier P. Characterization of in vitro healthy and pathological human liver tissue periodicity using backscattered ultrasound signals. Ultrasound Med Biol. 2006;32(5):64957.

10. Hoffmeister BK, Johnson DP, Janeski JA, Keedy DA, Steinert BW, Viano AM, Kaste SC. Ultrasonic characterization of human cancellous bone in vitro using three different apparent backscatter parameters in the frequency range 0.6-15.0 mhz. IEEE Trans. UFFC. 2008;55(7):1442-52. 11. Einhorn TA. Enhancement of fracture-healing. J Bone Joint Surg Am. 1995;77(6):940-56.

12. Selgaman KA, Clark GL. Un-united fractures of the distal radius: a report of 12 cases. J Hand Surg Am. 1998;23(5):914-9.

13. Smith VA, Wright TW. Nonunion of the distal radius. J Hand Surg Br. 1999;24(5):601-3.

14. Kokubu T, Hak DJ, Hazelwood SJ, Reddi AH. Development of an atrophic nonunion model and comparison to a closed healing fracture in rat femur. J Orthop Res. 2003;21(3):503-10.

15. Russel G, Tucci M, Conflitti J, Graves M, Wingerter S, Woodall J Jr, Rabag A, Benghuzzi H. Characterization of a femoral segmental nonunion model in laboratory rats: report of a novel surgical technique. J Invest Surg. 2007;20(4):249-55.

16. Grundnes $\mathrm{O}$, Rekeras $\mathrm{O}$. The importance of the hematoma for fracture healing in rats. Acta Orthop Scand. 1993;64(3):340-2.

17. Duarte LR. The stimulation of bone grow by ultrasound. Arch Orthop Trauma Surg. 1983;101(3):153-9.

18. Chakkalakal, DA, Strates BS, Mashoof AA, Garvin KL, Novak JR, Fritz ED, Mollner TJ, McGuire MH. Repair of segmental bone defects in the rat: an experimental mode human fracture healing. Bone. 1999;25(3):321-32.

19. Volpon JB. Nonunion using a canine model. Arch Orthop Trauma Surg. 1994;113(6):312-17.

20. Forriol F. The effect of shockwaves on mature and healing cortical bone. Int Orthop. 1994;18(5):325-9.

21. Khan Y, Laurencin CT. Fracture repair with ultrasound: clinical and cell-based evaluation. J Bone Joint Surg Am. 2008;90(1):138-44.

22. Schleberger R, Senge T. Non invasive treatment of long bone pseudarthrosis by shock waves. Arch Orthop Trauma Surg. 1992;111(4):224-7.

23. Wüster C, Hadji P. Use of quantitative ultrasound densitometry (QUS) in male osteoporosis. Calcif Tissue Int. 2001;69(4):225-8.

24. Chaffai S, Roberjot V, Peyrin F, Berger G, Laugier P. Frequency dependence of ultrasonic backscattering in cancellous bone: autocorrelation model and experimental results. J Acoust Soc Am. 2000;108(5):2403-11. 25. Wear KA. Anisotropy of ultrasonic backscatter and attenuation from human calcaneus: Implications for relative roles of absorption and scattering in determining attenuation. J Acoust Soc Am. 2000;107(6):34749.

26. Riekkinen O, Hakulinen MA, Lammi MJ, Jurvelin JS, Kallioniemi A, Töyräs J. Acoustic properties of trabecular bone - relationships to tissue composition. Ultrasound Med Biol. 2007;33(9):1438-44.

27. Wear K A, Stuber AP, Reynolds JC. Relationships of ultrasonic backscatter with ultrasonic attenuation, sound speed and bone mineral density in human calcaneus. Ultrasound Med Biol. 2000;26(8):1311-6. 28. Meziri M, Pereira WCA, Abdelwahab A, Degott C, Laugier P. In vitro chronic hepatic disease characterization with a multiparametric ultrasonic approach. Ultrasonics. 2005;43(5):305-13.

\section{Correspondence:}

Manoel Luiz Ferreira

Rua Orestes Barbosa, 48/Cob 01

21940-375 Rio de Janeiro - RJ Brazil

Phone (5521)9110-6183

louiz 25@yahoo.com.br
Conflict of interest: none Financial source: none

Received: August 18, 2009

Review: October 20, 2009 Accepted: November 19, 2009

\section{How to cite this article}

Ferreira ML, Matusin DP, Machado CB, Silva PC, Mello NB, Amaral AC, Franco RS, Pereira WCA, Schanaider A. Characterization of pseudarthrosis with ultrasound backscattered signals in rats. Acta Cir Bras. [serial on the Internet] 2010 Jan-Feb;25(1). Available from URL: http://www.scielo.br/acb 